\title{
㾞 料
}

フライコーム ボックス用ベアリングの諸問題“

次田義明些

\section{1. まえがき}

周知のようにフライコ一ムボ,クスはトノファの表 で、これに使巵するべアリングは偏心軸, 播動軸に使用 されるとい5特性上，一般の回転部分に使用される易合

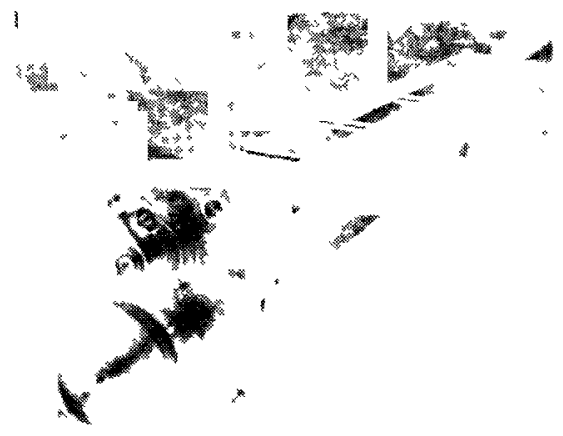

と異なった特別の考惫を払わなければならない，即ち摇 動通動を行う埸所のベアリノグは幾多の困難な問題を存 し、メタルの場合は種々不都合のことかあり，滑り運動 の方古か変動するため，その生命とする閏滑凮のポンプ アクションが十分行われず，境界摩擦状態となって摩耗 が甚しく，又駆動朝は荷重かフルクラムレハの運動に 徉って方向不定となり，閏滑状態を損うたぬに摩耗或は

（第 面よりウエブをかき取るコームに搖動運動を与えるもの

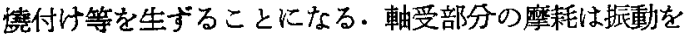
惹起し，旿動軸の運動が不正確となってコームの作動を 著しく阻害する結果となる。

しかしこれらの不都合な開題はフライコームホノク スの運動禨構に基くすので, ボール,ローラベリン グが摇動運動に対して有する利点は次のようなるのであ る

(1)転がり運動を行らため，閏滑凧のポンプアクン ョンを要せず, 往復運動に適している。

(2) 閏滑剤が適当に与えられれば，ペアリングの摩耗 は殆んと無く精度が維持できる。

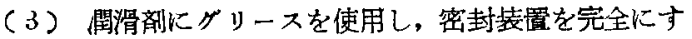
ればダリース補粭等の手数等か著しく省かれる。

(4) ダッース閏滑か適するため, 倬㖂を防ぐことかて きウェブを质損することかない。

以上のよ5な利点からホール、ローラ ペフリングか 使用されるのであるか, フライコーム ホ,クスの連動 の特殊性を十分認識し，その作動状態に適した使用をす るため，二，三の注意か必要であり，ベアリングの選 択, 主なる闍題点とそれに応ずる対策, 実験例, 紡積工 場に拈ける実例等を示し参考に供したい。

\section{2. フライコーム ホックスの譏粠}

第 1 図は改良された最新式のフライコームホノクス 表)

\begin{tabular}{|c|c|c|c|c|}
\hline No. & 名 & 軸 & 転 & 荷 \\
\hline 1 & $6304 \mathrm{ZZA}$ & 偏心，駆動軸用 & $1200 \sim 1400$ r.p.m. 全回枟 & $\begin{array}{l}\text { コ一台多びフルクラム レ八の慣性 } \\
\text { オ方向不定 }\end{array}$ \\
\hline 2 & $6305 \mathrm{ZZA}$ & " & " & $\|$ \\
\hline 3 & $6208 \mathrm{ZZA}$ & 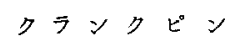 & $1200 \sim 1400$ r.p.m. & " \\
\hline 4 & $6302 \mathrm{ZZA}$ & コネクチンク ピン & $20 \sim 23 \mathrm{cycle} / \mathrm{sec}$ 角度 $13^{\circ}$ の搖動 & $\begin{array}{l}\text { コームの慣性力, 方向直径刘称に变 } \\
\text { 動 }\end{array}$ \\
\hline 5 & $\begin{array}{r}6207 \mathrm{ZZA} \\
\mathbf{3} \text { 個 }\end{array}$ & 搖 & $20 \sim 23 \mathrm{cycle} / \mathrm{sec}$ 角度 $16^{\circ} 52^{\prime}$ 摇動 & 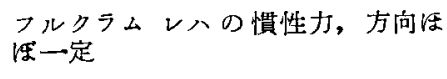 \\
\hline 6 & $6205 \mathrm{ZZA}$ & "（反呅側） & " & " \\
\hline
\end{tabular}

* Problems in Fly Comb Box Bearnng.

Y. Sawada，果洋ヘアリンク製追（株）生產部 


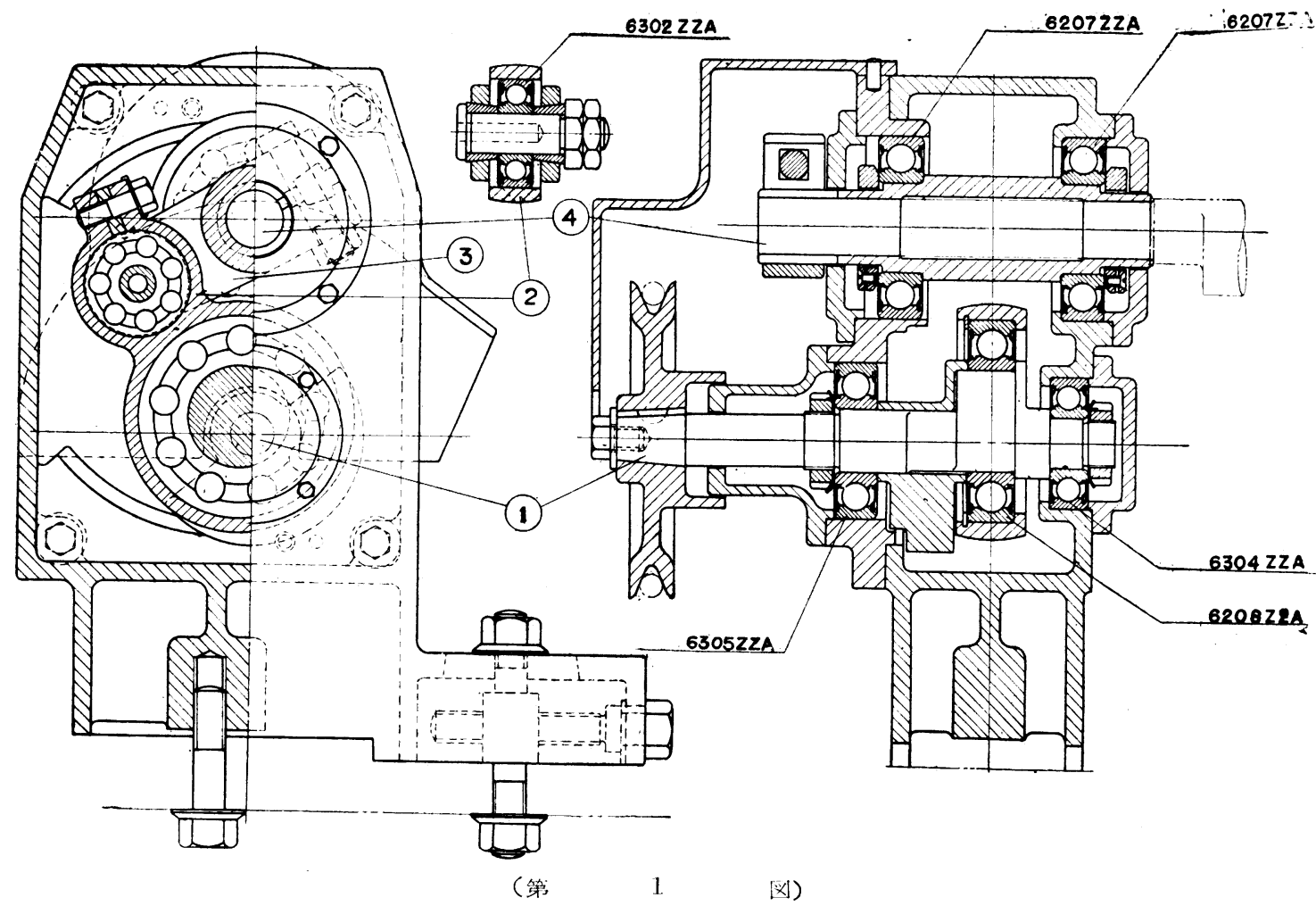

用バアリング装置り組立図の例で，駆動軸(1)の回転に伴 つてこの軸に偏心して取付けられたフルクラムレバ(2) が往復連動をし、アーム(3)を経て摇動軸(4)が摇動し、コ 一ムに摇動運動を与える。

駆動軸の回転数 $1200 \sim 1400$ r.p.m., 摇動軸由摇動[回 数 20〜23 cycle/sec, 摇動角約 $16^{\circ} 52^{\prime}$ 力゙樏準の運転条 件である、文これらの軸に取付けられているバアリング の運動と荷重の性質を第 1 表に示す.

第 1 表中, 運動条件, 荷重条件の㛜しいベアリングは 6208ZZA，6302ZZA でむって最も注意を要する部分で あり，次いで6304ZZA，6305ZZAである。

\section{3. 工場における使用例}

某紡績工場にて稼動された某メーカのフライコーム ボックスに使用されたボール ベアリングについて，そ のグリース インターバルを決定するため調查したとこ ろ, 次のような結果を得た。

\section{フライコーム ボックス駆動軸回転数 $1200 \sim 1300$ r.p.m.}

使用期間 2 ヶ年

使用グリース $\left\{\begin{array}{l}\text { OD No.1(Standard Vacuum) } \\ \text { DC } 4.4 \text { (Dow Corning) }\end{array}\right.$ 使用ベアリング 6304,6305 NU 208, 1302, 6207, 6207

1)グリースり泭着状態

ベアリングを取外したまま観察したところグリースい 我散は殆んど認められず，非常に良好な附着状態を示し ている. 又洗滌削後の重量よりグリース残存量を测定す ると第 2 表の如くであり, 同一寸法の密封型ベアリング

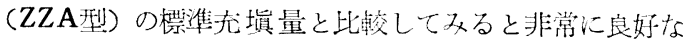
保持状態であることがわかる。

$$
\text { （第 } 2 \text { 表） }
$$

No. 品名 銘りー柄一残存グリ量 参考

\begin{tabular}{|c|c|c|c|c|c|c|}
\hline 6304 & OD & No. I & $2.5 \mathrm{~g}$ & $\begin{array}{l}6304 \\
\text { 標準 }\end{array}$ & $\begin{array}{l}Z Z A \\
\text { グリース }\end{array}$ & 量 $3.0 \mathrm{~g}$ \\
\hline 6305 & $\mathrm{DC}$ & 44 & 5.0 & 6305 & $\underset{\prime \prime}{Z Z A}$ & 4.0 \\
\hline NU208 & DC & 44 & 4.0 & 6208 & $\underset{\prime \prime}{Z Z A}$ & 6.5 \\
\hline 1302 & $\mathrm{DC}$ & 44 & 1.9 & 6302 & $\underset{\prime \prime}{Z Z A}$ & 2.2 \\
\hline 6207 & $\mathrm{OD}$ & No. 1 & 7.5 & 6207 & $\underset{1 /}{Z Z A}$ & 5.0 \\
\hline 6207 & OD & No. 1 & 10.0 & "I & "y & " \\
\hline
\end{tabular}

2) ベアリングの精傁

寸法及び回車精度の澌定㨁は第3 表に亦与上5に \#1302 を除いて良好であり，今後十分継繶使用できる。 


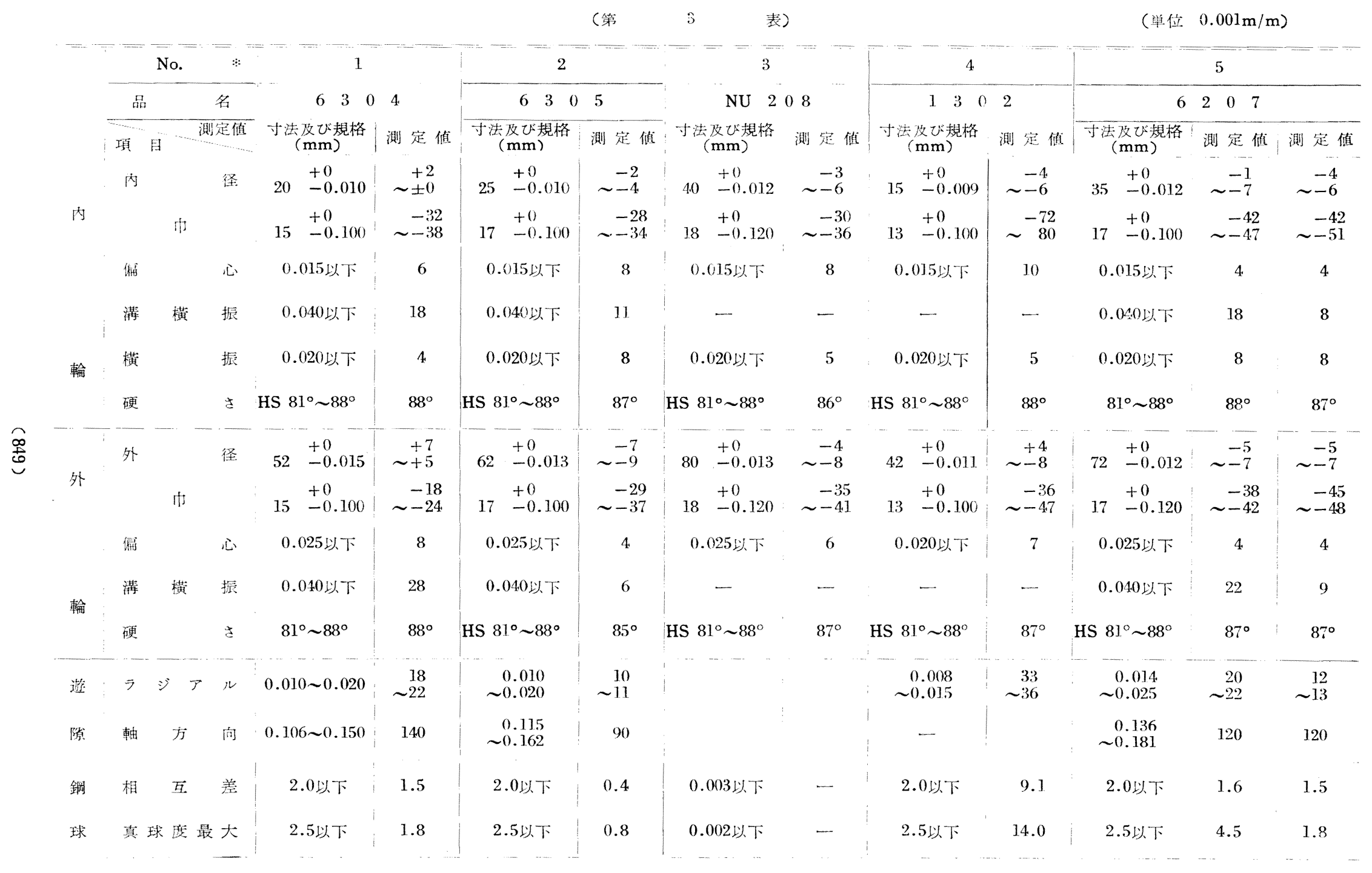

注 N No.法第1网, 第1表と同じく使用場所を示す 
ベアリングの摩耗状態はラジアル久は蟿方向遊隚の变化 によって知ることができるが，2 年開の使用に拘わらず

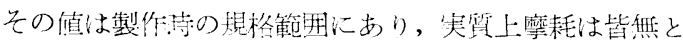
いらことができフフライコームの们動上必要欠くこと のできない性筫をボールベアリングが具備しているこ と少している。

これはベアリングが軸受鋼第 1 種及び第 2 種（JIS G 4805軸受鋼) を使用し, 硬さ $\mathrm{H}_{\mathrm{RC}} 60$ ～64 ( $\mathrm{H}_{\mathrm{S}} 81$ ～88) とい5高い值汇熱処理され高度の耐摩性を有しているこ とと，転がり運動を利用した本質的な特性とによるもの である・な怙１302 は多少その変化が大きく，これは主 に作動条件の苛酷なことによるものでこれにいいては 後述する。

\section{4. オーバロード試驗}

フライコームボックスの設尌化当っては, ベアリン グは通常寿命係数を 5 以上汉取り，摇動運動比上って発 生する未知の力や，不規則な運動化 万悪条件を加沫し て安全に没計されている。従って祭準条件で運転すれば ベアリングが故障する迄には上例が示すように極めて長 時間揱することになるので，試験条件としては苻酷では あるが、コームの慣性を增したり，駆動軸の回転数を上。
げて，短時間で結果をしることが望委しい。このような 条件で試験与れば，単化軸受に加わる荷重が増加するだ けでなく、慣性に件ら複雑な運動の影響を多くしたり,

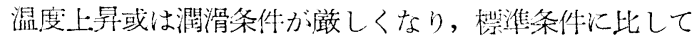
著しく荆酷になる・この意味でコ一ムの慣性力を約 2 倍 にし，駆動軸の回転を 2000 r.p.m.にしたところ $100 \mathrm{hr}$ 余りで摇動軸が折損した例があるが、ベアリングに異常 はなかった。この尒備実験より慣性モーメント 185 $\mathrm{kg} \mathrm{cm}{ }^{2}$, 回転数 1400 r.p.m. 汇決定し， $120 \mathrm{hr}$ 連転後 の精度の変化を調査した。

1) 試験条件

試駼ベアリング

6305Z, 2 個, NU305, 1205K, $6304 Z, 6307 Z$

回 転数 1400 r.p.m.

慣性モーメント $185 \mathrm{~kg} \mathrm{~cm}^{2}$ (実際の場合は $95 \mathrm{~kg} \mathrm{~cm}^{2}$ )

運転 時間 $122 \mathrm{hr}$

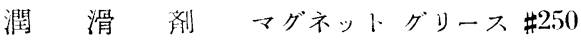

慣性モーメント $95 \mathrm{~kg} \mathrm{~cm}^{2}$ のときクランクピン ベア リング (No.2) に働く慣性力は $76 \mathrm{~kg}$ であるが， 185 $\mathrm{kg} \mathrm{cm}{ }^{2}$ では約 $127 \mathrm{~kg}$ となり, ベアリングの寿命につ

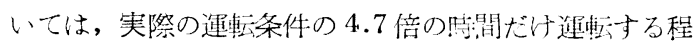
(第 4 表)

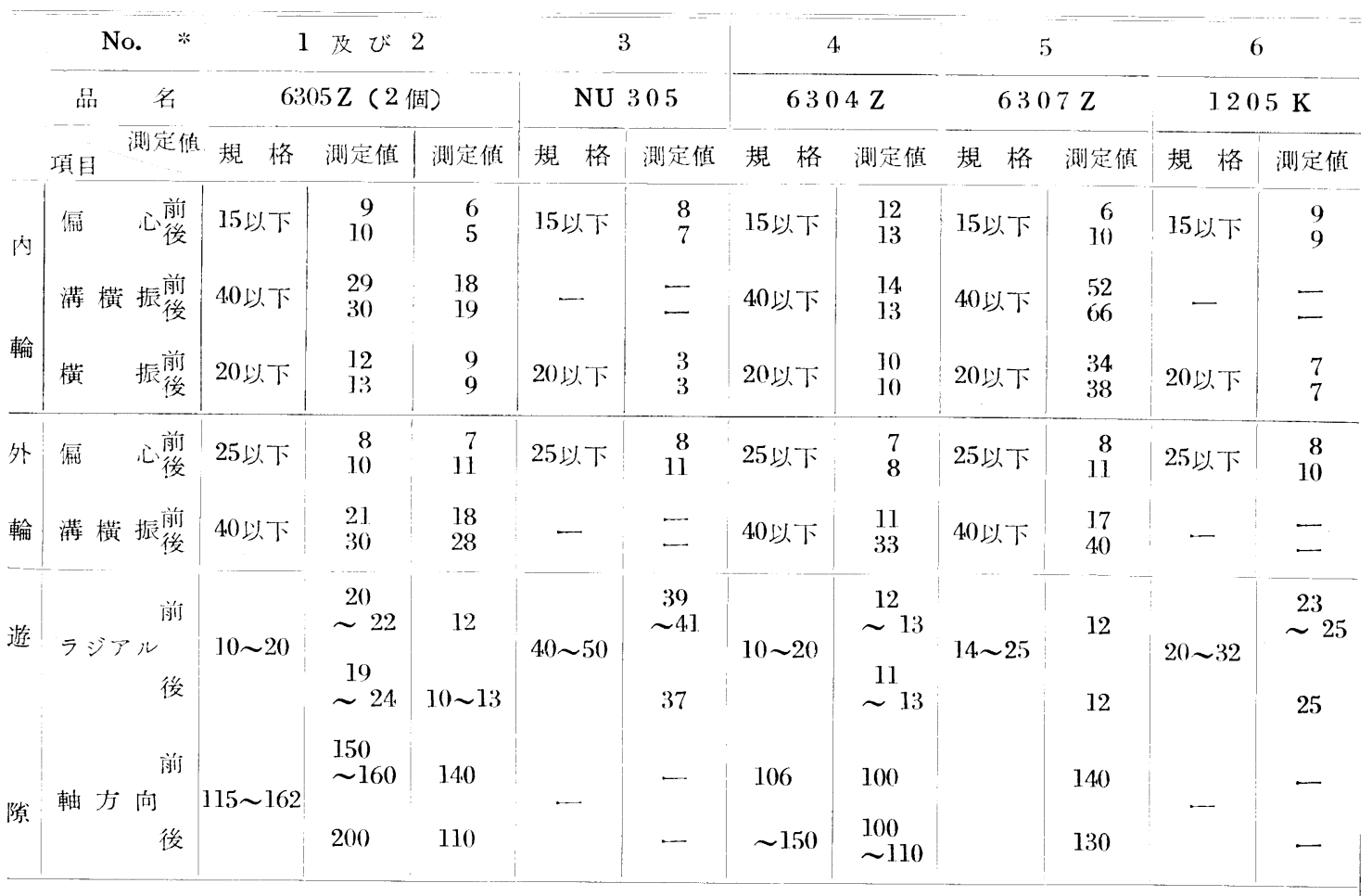

註* No. 法第 1 表と同じ使用場所を示す。 
の莉酷さに相当する・

2) 試 験 結 果

全般的にベアリングの異状は認められなかった。但し コネクチングシャフトのベアリング \#6304 の內輪が軸 方向に動いた形跡が認められたがこれは內輪とピンの 締代が殆んど0であったことによるものである・この現 象は好ましくないので內輪を固定するには軸公差を $m_{2}$ 程度に仕上なければならない。

グリースはいずれのベアリングにも相当量保持されて いて良好な状態であり, 各ベアリングの運転前後の精度 変化は第4 表に示与上5に，いずれも規格以內で良好で あったが，外輪の溝横握の变化が多少大きくなってい

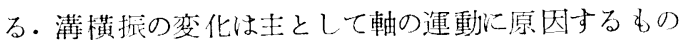
で, 各軸の平行度とか, 左右のベアリング, ハウジング の軸芯の不一致，又は周の直角度が覀い蛙に生ずるもの であるからこれらの精度を高くすると共に潤滑を完全 にすることが大切で，摇動運動をする部分では特に重要 なことである。この試験では比較的グリースの飛散がな く, ベアリングの精度变化に好結果を与えている・㵎滑 については後述する。

\section{5. ベアリングの故障}

フライコームボックス用ベアリングで生ずる故障 は, 摇動軸, クランクピン用のベアリングであり, 運 動状態の特異性に起因するすのであるので, 実際に生じ た現象を説明しその対策を考えてみたい。

1)內外輪レース面に発生与る凹及

使用けコームの摇動運動が悪くなり掎動が大きくなっ たベアリング \#6207 (2 個) を分解し調査したところ， 第2 図に示与上万に內外輸レース面にボールと等間隔の 凹川みが発生していた・文肖门述の調査軸受中コネクチング ビン用\#1302 のレース面以も同様な現隹が見らい，同 じく第2図にレース面のスタッチを示す。

これらの現像はいずれむ队輸が全回転せず，一年の角 度を租動するため発生するものであることは疑う余地の ないるのであるが，更に詳細に観察与る時，実際の山み の巾は摇動角より理論的に求めた探巾 $3.3 \mathrm{~mm}$ (世6207 內輪)，5.0 mm (廿6207 外輪) に比べて善があり，鋼球 の慣性力とか，不完全な転動の加わっていることを示し ている. 又\#1302 では內輪のレース面には四みはない が, 外輸のレース面には発生して招り, 鋼球とレース面 の接触条件の相遠の影響を示している・

この山みの生ずる現象は Fretting Corrosion(微動)

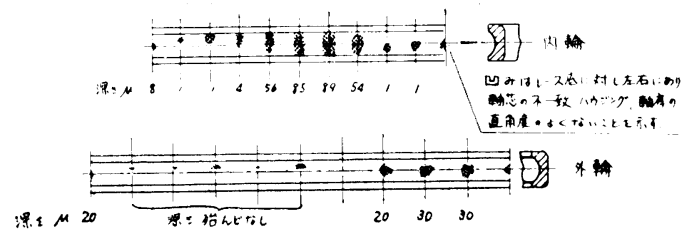

(a) $\$ 6207$ レース面展開図

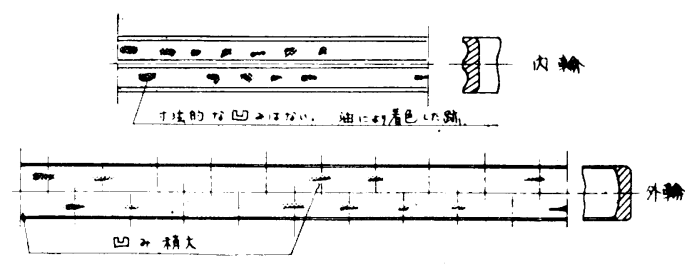

(b) \#1302レース面展開困

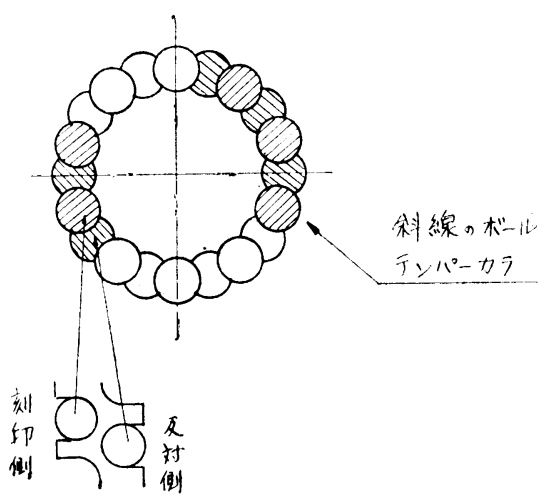

(c) \$1302ボール外観状熊

(第 2 润)

摩耗）といわれて最近盛んに研究の対像になっている閒 題で，接触点が僅かの荷重をうけ振動的な滑りを生ずる 場合, 接触面間比分子力が作用儿, 又電気化学的な作用 によってむる種の摩耗を発生するものでよく見られる 例としては貨車積みの輸送をしたり，或は船船用モータ で運転中止している時二軸方向の拁動をうけて発生す る・この際ボール ベアリングには全然という程生じない が，ローラベアリングには陆く発生し易く接触条件に よーて発生する度合が異なること寺与・ボールベアリ ングの場合，かような軸方问の掀動に対してもボールは 軪方向に転がり運動をしているため発生の少いものと思 われる・これと全く同じ理由で前述の 久艺生じているのは，その外輪の曲げ率が，その內輪や その他の深溝型より大きいことによる. 又上記の\#6207 は摇動のためグリースが飛散し，ベアリング中のグリー スは僅少となり, 活損したため, 接触面を保護する能力 を去ったことも加わっている・フレッチングコロージ ョンに対し接触面に働く物理化学的作用を減少し, 面を 保護するため, 潤滑剤のもつ役割は非常に大きく, 又振 
動或は微少の摇動汇よる慣性力に対し，ダンバの作用る 要求されるものである.

2 ) 故障の㛊策

內外輸レース面汇発生する四みはフレッチングコロ ージョンといわれるもので，その原因は微小の滑がり運 動と洞滑剤の欠除，又は老化汇原因するものであるの でベアリングの故障を防ぐには次のような諸点に舀意 せわばならない。

（a）接触面聞の滑りを少くするため，接触状態はでき る限り二面の曲率を近ずける。この点深溝型ボール ベアリング 6200, 6300 型が, シリンドリカル NU $200, N U 300$ 型或は自動調心型 $1200 ， 1300$ 型上り すぐれている。

（b）摇動運動に対しベアリングの転動を完全にするた わ，遊暻をできる限り小さくするのが好ましい。

（c）潤滑剤は耐圧性の十分大きなものを選定し，面の 保護を完全にする。

（d）摇動運動によってグリースは飛散し易いので，耐 飛散性と粘着力の大きいものを選灾。これは同時に 慣性力のダンパにも好都合である。

（e）グリースの飛散汇対し密封装置を完全にすると共 に，押出されたグリースが不必要の場所付附着しな いようハウジング內の空隙を少くする.

\section{6. 潤滑とベアリングの型式}

これ迄使用例，故障例で説明したように，良好な使用 状態の場合は必ずグリースが十分保有されており，そ5 でない場合は山及を生じたり，精度が低下したりするの でグリースの果している役割は非常に大きい.フライ コームボックス用ベアリングの運動はグリースを㹉り 飛ばし易い動きを行うので長期閂ベアリング內部に保有 され，且つレース面を完全化保護する役割を果すために は，十分グリースの選定と潤滑法を検討しなければなら ない. 即ち，グリースの具備すべき条件として

(a) ベアリングのレース面に附着し容易に振り飛ばさ れないよらな稢着性を有すること, 即ち耐飛散性が あること

(b) 密封部分よりの漏洩の少いこと

(c) 潤滑性能が優秀であること

(d) 耐久性を有すること

である。

久グリースの飛散或は漏洩を防ぐためには，ハウジン グ內の空隚や密封装置の設計は非常に重要なことである
が，前述のようにフライコームボックス用ペアリング として啇した深溝型ボール ベアリングには密封型とい われるものがあり，非常に良好の成績を修めている。

1）密封型ベアリング

密封型ベアリングとはベアリングの側面の部分に密封 装置を內臓したもので, 寸法, 負荷容量共普通のものと 变らず,ベアリング內部に予め選定されたグリースを封 大し，長期間グリースの補給なしに使用できるべアリン グである．密封装置の型式にはスナップ リングによっ て取外すことのできる鉄板製シールプレートを外輪に 固定したものと，合成ゴム製のシールプレートをその 弾力で外輪に固定したものがあるが，シールプレート の老化による寿命の点で鉄板製シール プレートのもの がフライコームボックス用に最適で“ZZA 型”と呼ば れている. その構造は第 3 図に示寸通りシール プレー トの先端が內側化折込まれ，內輸の肩の部分でラビリン スを形成し，密封作用を完全にすると共にプレートは スナップ リングを外すことによって取外すことができ， 必要に応じグリースを補給できる便利さを有している。

ZZA 型密封べア リングでは摇動運動 により外周方向には ね飛ばされるグリー スをシールプレー トによって防ぎ, 比 較的少量で十分潤滑 作用を行いらる。そ

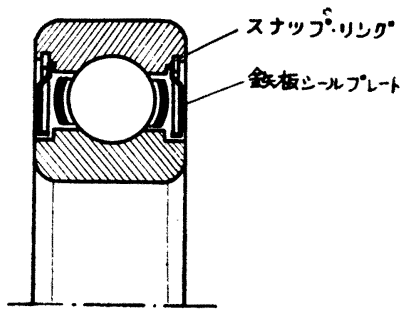

(第3図) ZZA 形
のためハウジングの設鄉を簡略にし，グリースの節約が できると共に，外部からの蝔埃の侵大を防止し，グリ一 スの寿命が長くなる.フライコームボックス使用寸 る時は普通回転軸では $3 \sim 4$ 作, 摇動軸で $2 \sim 3$ 作間取 替えずに継続使用できる。

2) 潤滑グリース

市販されているグリースの種類は非常に沢山あるが， グリースの選択はフライコームボックス用ベアリング の生命であり，前述のような墸特性を有することが必要 である・

グリースの粘着性は土として石羷基に負うところが大

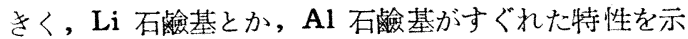
し，又特殊なるのとしては Bentonite clayを用いたも の子有効と考えられる. 又摇動運動ではグリースが剪断 される率が非常に大きく，ASTM で規定されているワ 一クによる軟化とか，組織の破壞に対しすぐれたもので なければならない。このようなことから現在一般に多く 
用いられているグリースで成績のよいものは $\mathrm{Li}$ 石哈基 のものではシリコングリースがあり, Bentonite clay 系のグリースは今後研究されるべきものと思われる.

密封性能についてはグリースの種類によって著しく差 があり，その性筫は主として石鹼基によるもので，密封 型ペアリングを用いてグリースの漏洩度を実験した結果 は第 5 表のようであって,グリースの種類による程传の 差を知ることができる。

\section{（第 5 表）}

グリース銘唡石鹼基|漏洩量|漏洩度

\begin{tabular}{|c|c|c|c|}
\hline Alvania No. 2 & $\mathrm{Li}$ & 6.3 & 40.6 \\
\hline $\begin{array}{l}\mathrm{DC} 44 \mathrm{M} \\
(\text { (シリコングリース) }\end{array}$ & $\mathrm{Li}$ & 5.8 & 37.4 \\
\hline マグネット \#250 & $\mathrm{Na}, \mathrm{Ca}$ 湿食 & 11.9 & 76.8 \\
\hline \multicolumn{4}{|l|}{ 武 験 条 件 } \\
\hline 弑 騃 軸 受 & \multicolumn{3}{|l|}{$6307 \mathrm{ZZA}$} \\
\hline グリース封大筸 & \multicolumn{3}{|l|}{$15.5 \mathrm{~g}$} \\
\hline 谷 & \multicolumn{3}{|l|}{ 常 温 } \\
\hline 澌 & \multicolumn{3}{|c|}{$\begin{array}{l}\text { 荷重 } 300 \mathrm{~kg} \text {, 回転数 } 3600 \mathrm{r} . \mathrm{p} . \mathrm{m} \\
\text { で } 3 \mathrm{hr} \text { 運転後 }\end{array}$} \\
\hline
\end{tabular}

この結果が示すように $\mathrm{Na}, \mathrm{Ca}$ 石硷基のグリースは 不適当である・又、グリースの潤滑性能孔具備寸心゙き西 要な性经であって, 前述の例に使用された各種のグリー スとその他著名なグリースについて4 球式油試験機によ る成績を第 6 表に示し，二，三考察してみよう。

(第
使用例から成績のよい $\mathrm{Li}$ 石伶基のグリースについて DC 44M シリコングリースはベースオイルとしてシリ コン油を使用していて耐熱性と耐飛散性は非常によい が，洬滑性能が更に良いものが望ましく、ベースオイ ルK鉝油を使用したりチュームグリースとして二,三 の銘杼が本販されていて, シリコングリース以上の成 績をおさめることが期待される。

\section{7. 結 び}

以上でフライコームボックス用ベアリングの諸特性 と潤滑グリースについて概要の説明をしたが，これらの

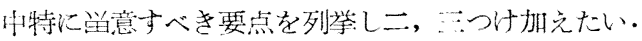

(1) 摇動部分のベアリングには深瑇型ボールベアリ ングが適し，特に ZZA 密封型ベアリングはあらゆ る点に最適のむのといえる・回転部分のベアリング には ZZA 密封刑ベアリングか, 負荷容量の大きい シリンドリカルローラ ベアリングが適している.

（2）ベアリングの寸法精度，回転精度は長期間の使用 によっても殆んど変化のないことが噼められている ぶ, 靴橫挔の变化に対しては軸芯のくるい, 軸や八 ウジングの局の直角度が影響するので，この点特に 注等し加工精度を上げなければならない。

（3）取付けられただアリングが適正な遊炫を持り，IF

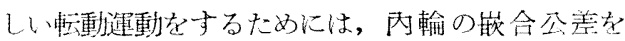
$\mathrm{JES} m_{2}$ にすることによって得られる。

表)

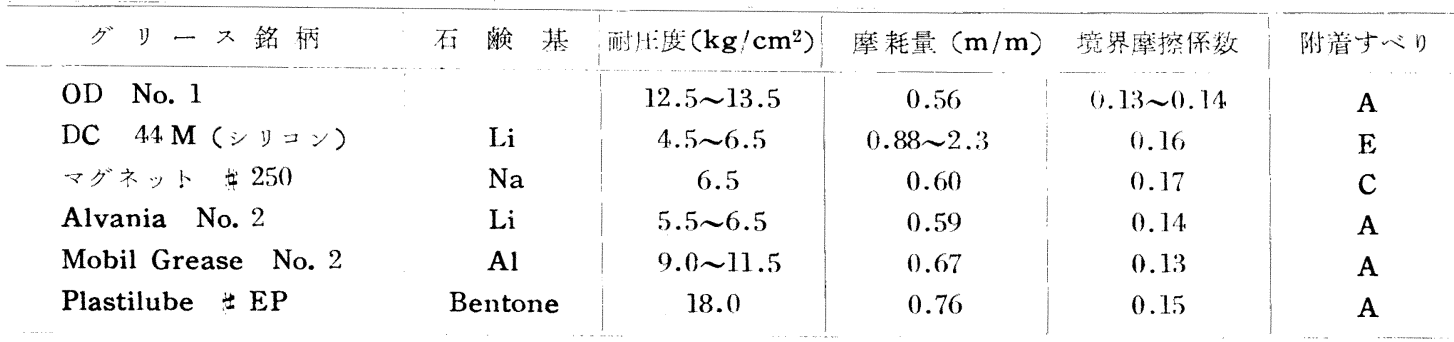

前の使用例で成績の良好であったグリース OD No. 1, DC 4.4M 其粘着州がよいことによるもので, OD No. 1 は濞滑性能む非常に好い優秀なグリースであるが，DC 44Mは潤滑性能は余り好くないが耐飛散性が大きい.又 マグネット \#250は潤滑性能は DC 44 M より良好であ るが，粘着性，密封能が悪く好ましくない、Mobil

Grease, Plastilube のよ 5 K Al 石羷基や Bentonite clay 基のグリースは粘着性もよく, 潤滑性もよいが前 者は耐熱性にとぼしく，後者は防鈕能に難点があり，今 後研究の対像とすべきものと思われる。
（4）は权飛ばされ易い通動を5けるベアリングにとっ て,グリースの耐飛散性と粘着性は最大の必须条件 で, Li 石鰫基のグリースが好結果を得ている。 結局フライコームボックス用ベアリングの生命はグ リースの良否によるもので, 潤滑性能のすぐれた Li 石

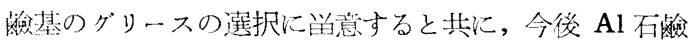
基域は Bentonite clay 基のグリースについてそれら のもつ众を改良し，その使用を研究すれば，ベアリン グの精度を更に長時間確保でき, 著しく寿命を越げすこ とが可能と考えられる。 